\title{
DNA methylation for cervical cancer screening: A validation trial in China
}

\section{Linghua Kong}

Peking Union Medical College Hospital

\section{Linhai Wang}

Beijing SinoMDgene Technology Co., Ltd

\section{Ziyun Wang}

Beijing SinoMDgene Technology Co., Ltd

\section{Xiaoping Xiao}

Peking Union Medical College Hospital

\section{Yan You}

Peking Union Medical College Hospital

\section{Huanwenn Wu}

Peking Union Medical College Hospital

\section{Ming Wu}

Peking Union Medical College Hospital

\section{Pei Liu}

Beijing SinoMDgene Technology Co., Ltd

\section{Lei Li ( $\square$ lileigh@163.com )}

Peking Union Medical College Hospital https://orcid.org/0000-0001-8723-3461

\section{Research}

Keywords: Cervical cancer, cervical intraepithelial neoplasia, DNA methylation, high-risk human papillomavirus, validation set, endometrial carcinoma

Posted Date: October 1st, 2020

DOI: https://doi.org/10.21203/rs.3.rs-84125/v1

License: @ (i) This work is licensed under a Creative Commons Attribution 4.0 International License. Read Full License 


\section{Abstract}

Background Based on published results from a training set, EPB41L3 and JAM3 gene methylation status had favorite results compared with high-risk human papillomavirus (hrHPV) testing. This validation trial evaluated the DNA methylation status and genotyping of hrHPV in unselected patients with gynecologic diseases.

Methods This study enrolled all patients in the study center from June 1, 2019 to September 1, 2019. Liquid-based samples were collected from cervical swabs for methylation assays and hrHPV testing one day before surgery. The primary endpoint was the diagnostic accuracies of DNA methylation and hrHPV genotyping for cervical intraepithelial neoplasia (CIN) 2 or more severe lesions (CIN2+).

Results In total, 307 patients were included in the final analysis, with a median age of 46 years. The sensitivity, specificity, positive predictive value (PPV) and negative predictive value (NPV) of the methylation assay for CIN2+ were $68.7 \%, 96.7 \%$, 0.933 and 0.712 , respectively, and the methylation assay achieved similar diagnostic accuracies to those in the training set and to hrHPV testing. Even in patients with negative hrHPV results, DNA methylation was significantly able to identify CIN2+ (odds ratio 39.857, 95\% confidence interval 7.137-222.577). The methylation assay was sensitive for CIN2/3 and cervical squamous cell carcinoma without residual lesions and was not positive in this context.

Conclusion For the diagnosis of cervical adenocarcinoma, methylation assessment, hrHPV testing and their combination had favorable results in all subtypes.

\section{Background}

Uterine cervical cancer is one of most common causes of cancer-related deaths among women globally[1] and in China.[2] Chinese patients account for $28 \%$ of the total number of new cases of cervical cancer worldwide.[3] Robust and standard screening programs would significantly decrease the prevalence of cervical cancer.[4] Currently, cervical cytology and/or highrisk human papillomavirus (hrHPV) are the mainstream screening methods; $[5,6]$ however, both cytology and hrHPV have limitations in terms of their diagnostic accuracies.[7, 8] Thus, a cost-benefit analysis is essential for decision-making in cervical cancer screening.[9] A new screening strategy with high accuracy and feasibility is urgently needed in developing countries such as China. DNA methylation is an epigenetic mechanism that results in heritable silencing of genes without changes to their coding sequences.[10,11] More than 100 human (host) genes have been reported to be possible methylation biomarkers of cervical cancer.[12] Genotyping and methylation markers are objective and can be used with self-obtained samples, offering great advantages in low- and middle-income settings.[9] Numerous studies have shown that methylation has a favorable screening sensitivity for cervical intraepithelial neoplasia (CIN) 2 or more severe lesions (CIN2+, or high-grade intraepithelial lesions [HSIL]) as a triage method in women with positive hrHPV status. Multiple panels have been utilized as classifiers consisting of dozens of candidate host genes, viral genes or both as well as various combinations thereof.[13]

In our previous exploratory study,[14] assessment of the combination of EPB41L3 and JAM3 methylation had a similar diagnostic accuracy to that of hrHPV testing for detecting CIN2+, which suggested that DNA methylation may be the preferred screening method regardless of hrHPV status. In this validation set, EPB41L3 and JAM3 gene methylation assessment and hrHPV genotyping were used to evaluate cervical liquid-based samples before major surgery from unselected patients with various diseases in a gynecologic oncology unit. The diagnostic accuracies of various screening strategies were compared.

\section{Methods}

\section{Ethical approval}

The institutional review board from the study center approved the study (No. JS-1954). All patients provided their consent before enrollment. The registration number is NCT03960879 (clinicaltrials.gov, registered on May 23, 2019). All procedures in 
the study involving human participants were in accordance with the ethical standards of the institutional and national research committee and with the 1964 Declaration of Helsinki and its later amendments or comparable ethical standards.

\section{Study design}

The study was performed in a prospective cohort with patients who were ready for conization, the loop electrosurgical excision procedure (LEEP) or hysterectomy for various gynecologic diseases. In such situations, the cervical histology could be evaluated sufficiently. Before surgery, liquid-based samples was collected from cervical swabs and analyzed for both DNA methylation and hrHPV genotyping. The accuracies of DNA methylation, hrHPV genotyping and the combination were compared for various surgically confirmed cervical pathological types. The primary endpoints were the diagnostic accuracies of DNA methylation and hrHPV in liquid-based cytology specimens for CIN2+. The secondary endpoints were the diagnostic accuracies of DNA methylation and hrHPV for CIN2+ with or without residual lesions and for specific pathological types, including cervical adenocarcinomas (ADCs) and endometrial and ovarian tumors.

\section{Patient enrollment}

This study enrolled all patients who were ready for surgery in one gynecologic oncology unit of the study center from June 1, 2019, to September 1, 2019. Data regarding the patients' epidemiological characteristics and medical histories were obtained from the medical records and supplemented by interviews with the patients. The inclusion criteria were as follows: aged 18 or older; confirmed CIN2/3 or with definite cytology and/or hrHPV screening results without intervention according to the screening guidelines of the American Cancer Society, American Society for Colposcopy and Cervical Pathology, and American Society for Clinical Pathology [5] and its updated version[6]; consent for conization, LEEP or hysterectomy, with relevant pathological results obtained; negative HIV results; no history of organ transplantation or use of immunosuppressive therapy; and willingness to participate in the study. Cases not meeting all the criteria were excluded. All histological materials were reevaluated by two pathologists ( $\mathrm{YY}$ and HW). For patients with CIN2/3 or cervical cancer as the primary diagnosis, pathological results before and after surgery were checked meticulously to confirm whether there were residual lesions, since biopsy or excision for diagnosis before the last surgery would eliminate the primary lesion.

\section{Collection and assays of study materials}

One day before surgery, a liquid-based sample was collected from the cervical swabs and stored in PreservCyt Solution (Thinprep Pap Test; Hologic, Marlborough, MA, USA) at room temperature.

The assays for DNA methylation and hrHPV have been described previously.[14] Methylation of the EPB41L3 and JAM3 genes was evaluated using TaqMan-based technologies with the Methylated Human EPB41L3 and JAM3 Gene Detection kit (real-time fluorescent polymerase chain reaction [PCR]) (Beijing SinoMDgene Technology Co., LTD, China) and an ABI 7300 Real Time Fluorescence Quantitative PCR system (Life Tech, USA). The methylation level of each gene was determined by the $\triangle \mathrm{Ct}$ value (the target gene $\mathrm{Ct}$ value subtracts the reference gene $\mathrm{Ct}$ value). Positive status was defined as a $\triangle \mathrm{Ct}$ value less than 7.945 and 9.250 for EPB41L3 and JAM3, respectively. Total methylation status was defined as positive EPB41L3 and/or JAM3 methylation.

No matter whether the patients previously received hrHPV testing or not, hrHPV genotyping was uniformly performed with TaqMan-based technology using an ABI 7500 Real Time Fluorescence Quantitative PCR system (Life Tech, USA) or a Stratagene Mx3000p Fluorescence Quantitative PCR system (Stratagene, USA) with an HPV nucleic acid genotyping diagnostic kit (Real time Fluorescent PCR) (Beijing SinoMDgene Technology Co., Ltd, China). The diagnostic kit detects a pooled result for hrHPV types, including HPV $16,18,31,33,45,52,6,11,35,51,39,59,68,56,58$, and 66, with type-specific probes.

\section{Statistics}


Nonnormally distributed variables and categorical data were compared between different screening groups by using nonparametric tests. The specificity, sensitivity, negative predictive value (NPV) and positive predictive value (PPV) were also calculated for various screening groups. The odds ratio (OR) and $95 \%$ confidence intervals $(95 \% \mathrm{Cls})$ of the positive ratios of different screening methods for various histological types were calculated with Logistic regression models. Unless otherwise stated, all analyses were performed with a two-sided significance level of 0.05 and were conducted with the use of Statistical Product and Service Solutions Statistics 20.0 (IBM Corporation, Armonk, NY, USA).

\section{Results}

\section{Patient characteristics}

A flow diagram of the study is provided in Figure 1. From June 1, 2019, to September 1, 2019, 368 eligible patients were recruited, and 307 were included in the final analysis. The median age was 46 years (range 22 to 77 ). Regarding primary diagnoses, there were 41 cases of benign ovarian or uterine disease, 101 of CIN2/3, 66 of cervical cancer, and 99 of ovarian or uterine malignancies, precancerous lesions, or borderline tumors (Table 1 and Supplement 1). The surgeries comprised 84 cases of conization or LEEP and 223 hysterectomies. The final cervical pathology results are listed in Table 1 and Figure 1. The median interval from biopsy to conization/LEEP or from conization/LEEP to hysterectomy/radical hysterectomy was 40 days (range 10 to 51 ).

Table 1

Cervical procedures and pathology before and after sampling for DNA methylation. Three cases were excluded from the table, including one cervical mucinous adenocarcinoma, one uterine clear cell carcinoma, and one vaginal melanoma. ADC, adenocarcinoma. CIN, cervical intraepithelial lesion. LEEP, loop electrosurgical excision procedure. SCC, squamous cell carcinoma.

\begin{tabular}{|c|c|c|c|c|c|c|}
\hline \multirow[t]{2}{*}{ Primary diagnosis } & \multicolumn{3}{|c|}{$\begin{array}{l}\text { Cervical procedures } \\
\text { methylation (n) }\end{array}$} & \multicolumn{2}{|c|}{$\begin{array}{l}\text { Surgeries after DNA methylation } \\
(\mathrm{n})\end{array}$} & \multirow[t]{2}{*}{$\begin{array}{l}\text { Actual cervical pathology after DNA } \\
\text { methylation }\end{array}$} \\
\hline & None & Biopsy & Conization or LEEP & $\begin{array}{l}\text { Conization or } \\
\text { LEEP }\end{array}$ & Hysterectomy & \\
\hline Benign $(n=41)$ & 41 & 0 & 0 & 0 & 41 & $\begin{array}{l}\text { Inflammation }(\mathrm{n}=40) \\
\text { CIN1 }(\mathrm{n}=1)\end{array}$ \\
\hline CIN2/3 $(\mathrm{n}=101)$ & 0 & 84 & 17 & 84 & 17 & $\begin{array}{l}\text { Inflammation }(n=16) \\
\text { CIN1 }(n=13) \\
\text { CIN2 }(n=17) \\
\text { CIN3 }(n=55)\end{array}$ \\
\hline $\begin{array}{l}\text { Cervical } \quad \text { carcinomas } \\
(\mathrm{n}=66)\end{array}$ & 0 & 37 & 29 & 0 & 65 & $\begin{array}{l}\text { Inflammation }(n=21) \\
\text { CIN1 }(n=1) \\
\text { SCC }(n=25) \\
\text { ADC, villoglandular type }(n=3) \\
\text { ADC, in situ }(n=6) \\
\text { ADC, endocervical type }(n=9) \\
\text { ADC, mucinous type }(n=1)\end{array}$ \\
\hline Others* $(n=99)$ & 99 & 0 & 0 & 0 & 99 & $\begin{array}{l}\text { Inflammation }(\mathrm{n}=96) \\
\text { CIN1 }(\mathrm{n}=1) \\
\text { Endometrial clear cell carcinoma }(\mathrm{n}=1) \\
\text { Vaginal melanoma }(\mathrm{n}=1)\end{array}$ \\
\hline
\end{tabular}

* Others includes gynecological malignancies, precancerous lesions, or borderline tumors rather than cervical lesions.

DNA methylation and hrHPV assays were successfully performed for all 307 patients. There were 68 (22.1\%), 103 (33.6\%), 109 (35.5\%), 131 (42.7\%) and 72 (23.5\%) cases with positive EPB41L3, JAM3, EPB41L3 or JAM3, hrHPV and methylation plus hrHPV, respectively. The details are listed in Supplementary Table 1. In the whole cohort, patients with positive and negative methylation had similar ages $(45.9 \pm 10.0$ versus $47.9 \pm 12.1$ years, $p=0.143)$; however, patients with positive hrHPV were significantly younger than patients with negative hrHPV $(42.8 \pm 10.5$ versus $50.4 \pm 11.1$ years, $p<0.001)$.

\section{Diagnostic accuracies for cervical lesions}

The diagnostic accuracies of the various screening methods are listed in Table 2. The positive methylation status rates for normal pathology in the whole cohort and in the cohort with exclusions for gynecological malignancies, precancerous lesions, and borderline tumors were $26.0 \%$ (25/96) and 3.9\% (3/77), respectively (Table 2). Therefore, the normal pathology of benign diseases served as a reference. As shown in Table 2, methylation, hrHPV status and their combination were all significantly related to the severity of the cervical lesion. However, compared with the reference, DNA methylation and methylation plus 
hrHPV achieved only marginal differences in CIN2 (with p values of 0.055 and 0.065 ), probably due to the small sample size for this pathology.

Table 2

The diagnostic accuracies of DNA methylation, hrHPV and their combinations for the final cervical pathology. ADC, adenocarcinoma. CIN2+, cervical intraepithelial neoplasia (CIN) 2 or more severe lesion. hrHPV, high-risk human papillomavirus. N/A, not available. NPV, negative predictive value. OR, odds ratio. 95\% CI, 95\% confidence interval. PPV, positive predictive value. SCC, squamous cell carcinoma.

\begin{tabular}{|c|c|c|c|c|c|c|c|c|c|c|c|c|}
\hline \multirow{2}{*}{$\begin{array}{l}\text { Cervical } \\
\text { pathology }\end{array}$} & \multicolumn{3}{|c|}{ DNA methylation } & \multicolumn{3}{|l|}{ hrHPV } & \multicolumn{3}{|c|}{ HPV16 or HPV18 } & \multicolumn{3}{|c|}{ DNA methylation + hrHPV } \\
\hline & $\mathrm{n}(\%)$ & $\begin{array}{l}\text { OR } \quad(95 \% \\
\text { CI) }\end{array}$ & $p$ & $\mathrm{n}(\%)$ & $\begin{array}{l}\text { OR } \quad(95 \% \\
\text { CI })\end{array}$ & $p$ & n (\%) & $\begin{array}{l}\text { OR } \quad(95 \% \\
\text { CI) }\end{array}$ & $p$ & $\mathrm{n}(\%)$ & $\begin{array}{l}\text { OR } \quad(95 \% \\
\text { CI })\end{array}$ & $p$ \\
\hline $\begin{array}{l}\text { Normal in } \\
\text { benign } \\
\text { diseases* } \\
(\mathrm{n}=77)\end{array}$ & $\begin{array}{l}3 \\
(3.9)\end{array}$ & Reference & - & $\begin{array}{l}18 \\
(23.4)\end{array}$ & Reference & - & $\begin{array}{l}11 \\
(14.3)\end{array}$ & Reference & - & $\begin{array}{l}1 \\
(1.3)\end{array}$ & Reference & - \\
\hline $\begin{array}{l}\text { Normal in } \\
\text { others } \\
(n=96)\end{array}$ & $\begin{array}{l}25 \\
(26.0)\end{array}$ & $\begin{array}{l}8.685 \\
(2.511- \\
30.405)\end{array}$ & 0.001 & $\begin{array}{l}3 \\
(3.1)\end{array}$ & $\begin{array}{l}0.106 \\
(0.030- \\
0.375)\end{array}$ & $<0.001$ & $\begin{array}{l}0 \\
(0.0)\end{array}$ & $\begin{array}{l}0.000 \\
(0.000- \\
\text { N/A) }\end{array}$ & 0.996 & $\begin{array}{l}0 \\
(0.0)\end{array}$ & $\begin{array}{l}0.000 \\
(0.000- \\
\text { N/A) }\end{array}$ & 0.997 \\
\hline $\begin{array}{l}\text { CIN1 } \\
(n=15)\end{array}$ & $\begin{array}{l}0 \\
(0.0)\end{array}$ & $\begin{array}{l}0.000 \\
(0.000- \\
\text { N/A) }\end{array}$ & 0.999 & $\begin{array}{l}10 \\
(66.7)\end{array}$ & $\begin{array}{l}6.556 \\
(1.982- \\
21.683)\end{array}$ & 0.002 & $\begin{array}{l}5 \\
(33.3)\end{array}$ & $\begin{array}{l}3.000 \\
(0.860- \\
10.460)\end{array}$ & 0.085 & $\begin{array}{l}0 \\
(0.0)\end{array}$ & $\begin{array}{l}0.000 \\
(0.000- \\
\text { N/A) }\end{array}$ & 0.999 \\
\hline $\begin{array}{l}\text { CIN2 } \\
(n=17)\end{array}$ & $\begin{array}{l}3 \\
(17.6)\end{array}$ & $\begin{array}{l}5.286 \\
(0.966- \\
28.911)\end{array}$ & 0.055 & $\begin{array}{l}13 \\
(76.5)\end{array}$ & $\begin{array}{l}10.653 \\
(3.087- \\
36.764)\end{array}$ & $<0.001$ & $\begin{array}{l}6 \\
(35.3)\end{array}$ & $\begin{array}{l}3.273 \\
(1.004- \\
10.671)\end{array}$ & 0.049 & $\begin{array}{l}2 \\
(11.8)\end{array}$ & $\begin{array}{l}10.133 \\
(0.863- \\
119.205)\end{array}$ & 0.065 \\
\hline $\begin{array}{l}\text { CIN3 } \\
(n=55)\end{array}$ & $\begin{array}{l}38 \\
(69.1)\end{array}$ & $\begin{array}{l}55.137 \\
(15.205- \\
199.941)\end{array}$ & $<0.001$ & $\begin{array}{l}50 \\
(90.9)\end{array}$ & $\begin{array}{l}32.778 \\
(11.356- \\
94.611)\end{array}$ & $<0.001$ & $\begin{array}{l}33 \\
(60.0)\end{array}$ & $\begin{array}{l}9.000 \\
(3.902- \\
20.759)\end{array}$ & $<0.001$ & $\begin{array}{l}35 \\
(63.6)\end{array}$ & $\begin{array}{l}133.000 \\
(17.158- \\
1030.948)\end{array}$ & $<0.001$ \\
\hline $\begin{array}{l}\text { SCC } \\
(n=25)\end{array}$ & $\begin{array}{l}24 \\
(96.0)\end{array}$ & $\begin{array}{l}592.00 \\
(58.790- \\
5961242)\end{array}$ & $<0.001$ & $\begin{array}{l}22 \\
(88.0)\end{array}$ & $\begin{array}{l}24.037 \\
(6.443-\end{array}$ & $<0.001$ & $\begin{array}{l}21 \\
(84.0)\end{array}$ & $\begin{array}{l}31.500 \\
(9.068-\end{array}$ & $<0.001$ & $\begin{array}{l}22 \\
(88.0)\end{array}$ & $\begin{array}{l}557.333 \\
(55.190-\end{array}$ & $<0.001$ \\
\hline $\begin{array}{l}\mathrm{ADC} \\
(\mathrm{n}=18)\end{array}$ & $\begin{array}{l}14 \\
(77.8)\end{array}$ & $\begin{array}{l}86.333 \\
(17.392- \\
428.568)\end{array}$ & $<0.001$ & $\begin{array}{l}14 \\
(77.8)\end{array}$ & $\begin{array}{l}11.472 \\
(3.353- \\
39.255)\end{array}$ & $<0.001$ & $\begin{array}{l}12 \\
(66.7)\end{array}$ & $\begin{array}{l}12.000 \\
(3.726- \\
38.646)\end{array}$ & $<0.001$ & $\begin{array}{l}11 \\
(61.1)\end{array}$ & $\begin{array}{l}119.429 \\
(13.385- \\
1065.636)\end{array}$ & $<0.001$ \\
\hline $\begin{array}{l}\text { Normal* }^{*} \\
\text { or CIN1 } \\
(\mathrm{n}=92)\end{array}$ & $\begin{array}{l}3 \\
(3.3)\end{array}$ & Reference & - & $\begin{array}{l}28 \\
(30.4)\end{array}$ & Reference & - & $\begin{array}{l}16 \\
(17.4)\end{array}$ & Reference & - & $\begin{array}{l}1 \\
(1.1)\end{array}$ & Reference & - \\
\hline $\begin{array}{l}\text { CIN2+ } \\
(n=115)\end{array}$ & $\begin{array}{l}79 \\
(68.7)\end{array}$ & $\begin{array}{l}65.105 \\
(19.294- \\
219.611)\end{array}$ & $<0.001$ & $\begin{array}{l}99 \\
(86.1)\end{array}$ & $\begin{array}{l}14.143 \\
(7.094- \\
28.197)\end{array}$ & $<0.001$ & $\begin{array}{l}72 \\
(62.6)\end{array}$ & $\begin{array}{l}7.953 \\
(4.118- \\
15.362)\end{array}$ & $<0.001$ & $\begin{array}{l}70 \\
(60.9)\end{array}$ & $\begin{array}{l}141.556 \\
(19.043- \\
1052.225)\end{array}$ & $<0.001$ \\
\hline Sensitivity & 68.7 & & & 86.1 & & & 62.6 & & & 60.9 & & \\
\hline $\begin{array}{l}\text { Specificity } \\
(\%)\end{array}$ & 96.7 & & & 69.6 & & & 82.6 & & & 98.9 & & \\
\hline $\begin{array}{l}\text { PPV } \\
\text { NPV }\end{array}$ & $\begin{array}{l}0.963 \\
0.712\end{array}$ & & & $\begin{array}{l}0.780 \\
0.800\end{array}$ & & & $\begin{array}{l}0.818 \\
0.639\end{array}$ & & & $\begin{array}{l}0.986 \\
0.669\end{array}$ & & \\
\hline
\end{tabular}

* These cases excluded gynecological malignancies, precancerous lesions, or borderline tumors rather than cervical lesions.

† These cases only included gynecological malignancies, precancerous lesions, or borderline tumors rather than cervical lesions.

For the diagnosis of CIN2+, the sensitivities, specificities, PPVs and NPVs of the methylation assay in the previous training set [14] and in the current trial were all equal: $72.1 \%$ versus $68.7 \%(p=0.525), 91.5 \%$ versus $96.7 \%(p=0.120), 0.679$ versus 0.712 $(p=0.232)$, and 0.930 versus $0.963(p=0.552)$, respectively.

For the diagnosis of CIN2+, assays for methylation assessment, hrHPV testing, HPV 16/18 testing and their combination all had favorable results, with ORs of 69.105 (95\% Cl 19.294-219.611), 14.143 (7.094-28.197), 7.953 (4.118-15.362) and 141.556 (19.043-1052.225), respectively (Table 2).

- The sensitivity values of methylation assessment and the combination were lower than that of hrHPV testing $(68.7 \%$, $60.9 \%$ versus $86.1, p=0.002$ and $<0.001$ ), but that of methylation assessment was similar to that of HPV $16 / 18$ testing $(68.7 \%$ versus $62.6, p=0.331)$.

- The specificity values of both methylation assessment and the combination were significantly higher than that of hrHPV testing $(96.7 \%$ and $98.9 \%$ versus $0.696, p<0.001$ and $<0.001)$, and that of methylation assessment was also significantly higher than that of HPV $16 / 18$ testing $(96.7 \%$ versus $82.6 \%, p=0.002)$.

- The PPVs of both methylation assessment and the combination were significantly higher than that of hrHPV testing ( 0.963 and 0.986 versus $0.780, p<0.001$ and $<0.001$ ), and that of methylation assessment was also significantly higher 
than that of HPV $16 / 18(0.963$ versus $0.818, p=0.003)$.

- The NPV of methylation assessment, but not the combination, was similar to that of hrHPV (0.712 and 0.669 versus $0.800, p=0.158$ and 0.039$)$, and that of methylation assessment was also similar to that of HPV $16 / 18(0.712$ versus $0.639, p=0.221)$.

Even in patients with negative hrHPV results, DNA methylation assessment still had a significant discrepancy for CIN2+ (OR $39.857,95 \% \mathrm{Cl} 7.137-222.577)$. In this population, the sensitivity, specificity, PPV and NPV were $56.3 \%, 96.9 \%, 0.818$ and 0.899 , respectively.

Further analysis of CIN2/3 and cervical squamous cell carcinoma (SCC) is presented in Table 3. Regarding SCC with or without residual lesions, significant differences in the methylation assay $(p<0.001)$ and in hrHPV testing $(p=0.004)$ were evident; regarding CIN2/3 with or without residual lesions, significant differences in the methylation assay $(p<0.001)$ and in hrHPV testing ( $p=0.004)$ were evident. Regarding CIN2/3 and SCC without residual lesions after biopsy or excision, their methylation statuses were similar to those of benign uterine and ovarian lesions ( $p=0.999$ and 0.998$)$. Regarding cervical diseases with or without residual lesions, the positive hrHPV ratios were all significantly higher than those of benign uterine and ovarian lesions (all p values less than 0.05 , Table 3 ).

Table 3

The diagnostic accuracies of DNA methylation, hrHPV and their combination for cervical SCC and CIN2/3 with or without residual lesions. CIN, cervical intraepithelial neoplasia. hrHPV, high-risk human papillomavirus. N/A, not available. OR, odds ratio. 95\% CI, 95\% confidence interval. SCC, squamous cell carcinoma.

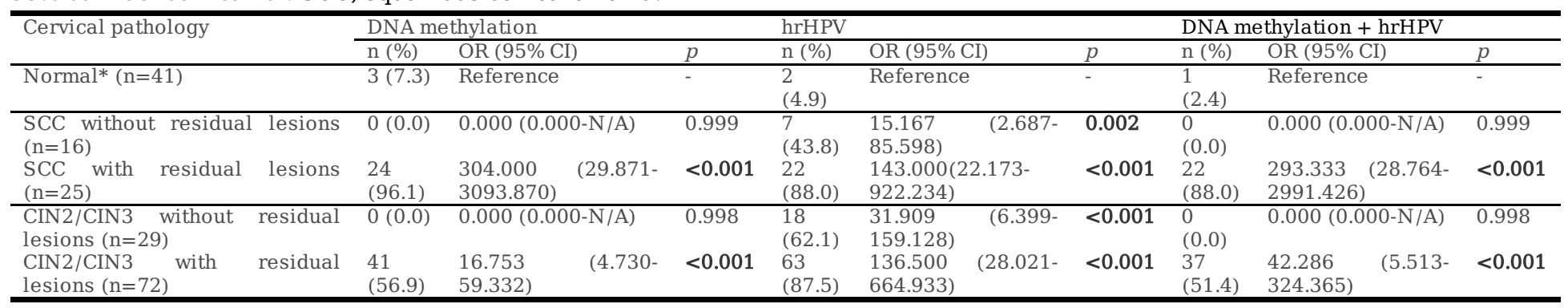

* These cases only included uterine or ovarian benign diseases

For the diagnosis of cervical ADC, methylation, hrHPV and their combination all had favorable results (Table 4). According to various subtypes of $A D C$, compared with uterine or ovarian benign diseases, methylation (OR 44.333, 95\% $\mathrm{Cl} 6.230-315.499$ ), $\operatorname{hrHPV}(156.000,12.575-1935.197)$ and their combination $(80.000,7.111-900.008)$ had the highest ORs in endocervical ADC, the most common pathology in this cohort. However, due to the limited sample size of ADC, the differences between the various subtypes of $A D C$ were not significant.

Table 4

The diagnostic accuracies of DNA methylation, hrHPV and their combination for cervical adenocarcinoma. ADC, adenocarcinoma. hrHPV, high-risk human papillomavirus. N/A, not available. NPV, negative predictive value. OR, odds ratio. 95\% CI, 95\% confidence interval. PPV, positive predictive value. SCC, squamous cell carcinoma. 


\begin{tabular}{|c|c|c|c|c|c|c|c|c|c|c|}
\hline \multirow[t]{2}{*}{ Cervical pathology } & \multicolumn{3}{|c|}{ DNA methylation } & \multicolumn{3}{|l|}{ hrHPV } & \multicolumn{4}{|c|}{ DNA methylation + hrHPV } \\
\hline & $\mathrm{n}(\%)$ & OR $(95 \% \mathrm{CI})$ & $p$ & $\mathrm{n}(\%)$ & OR $(95 \% \mathrm{CI})$ & $p$ & $\mathrm{n}(\%)$ & OR $(95 \% \mathrm{CI})$ & & $p$ \\
\hline Normal* $(\mathrm{n}=41)$ & $3(7.3)$ & Reference & - & $2(4.9)$ & Reference & - & $1(2.4)$ & Reference & & - \\
\hline $\begin{array}{l}\text { ADC, villoglandular type } \\
(n=3)\end{array}$ & $\begin{array}{l}3 \\
(100.0)\end{array}$ & $\mathrm{N} / \mathrm{A}(0.000-\mathrm{N} / \mathrm{A})$ & 0.999 & $\begin{array}{l}2 \\
(66.7)\end{array}$ & $\begin{array}{l}39.000 \\
634.654)\end{array}$ & 0.010 & $\begin{array}{l}2 \\
(66.7)\end{array}$ & $\begin{array}{l}80.000 \\
1801.650)\end{array}$ & (3.552- & 0.006 \\
\hline ADC, in situ $(n=6)$ & $\begin{array}{l}4 \\
(66.7)\end{array}$ & $\begin{array}{l}25.333 \\
199.68)\end{array}$ & 0.002 & $\begin{array}{l}4 \\
(66.7)\end{array}$ & $\begin{array}{l}39.000 \\
356.819)\end{array}$ & 0.001 & $\begin{array}{l}3 \\
(50.0)\end{array}$ & $\begin{array}{l}40.000 \\
511.879)\end{array}$ & (3.126- & 0.005 \\
\hline $\begin{array}{l}\text { ADC, endocervical type } \\
(\mathrm{n}=9)\end{array}$ & $\begin{array}{l}7 \\
(77.8)\end{array}$ & $\begin{array}{l}44.333 \\
315.499)\end{array}$ & $<0.001$ & $\begin{array}{l}8 \\
(88.9)\end{array}$ & $\begin{array}{l}156.000 \\
1935.197)\end{array}$ & $<0.001$ & $\begin{array}{l}6 \\
(66.7)\end{array}$ & $\begin{array}{l}80.000 \\
900.008)\end{array}$ & (7.111- & $<0.001$ \\
\hline $\begin{array}{l}\text { ADC, mucinous type } \\
(\mathrm{n}=1)\end{array}$ & $0(0.0)$ & $0.000(0.000-\mathrm{N} / \mathrm{A})$ & 1.000 & $0(0.0)$ & $0.000(0.000-\mathrm{N} / \mathrm{A})$ & 1.000 & $0(0.0)$ & $0.000(0.000$ & $-\mathrm{N} / \mathrm{A})$ & 1.000 \\
\hline Normal* $(\mathrm{n}=41)$ & $3(7.3)$ & Reference & 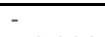 & $2(4.9)$ & Reference & 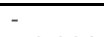 & $1(2.4)$ & Reference & & - \\
\hline $\operatorname{ADC}(\mathrm{n}=19)$ & $\begin{array}{l}14 \\
(73.7)\end{array}$ & $\begin{array}{l}35.467 \\
168.274)\end{array}$ & $<0.001$ & $\begin{array}{l}14 \\
(73.7)\end{array}$ & $\begin{array}{l}54.600 \\
314.148)\end{array}$ & $<0.001$ & $\begin{array}{l}11 \\
(57.9)\end{array}$ & $\begin{array}{l}55.000 \\
488.166)\end{array}$ & (6.197- & $<0.001$ \\
\hline Sensitivity (\%) & 73.7 & & & 73.7 & & & 57.9 & & & \\
\hline Specificity (\%) & 92.7 & & & 95.1 & & & 97.6 & & & \\
\hline PPV & 0.824 & & & 0.875 & & & 0.917 & & & \\
\hline NPV & 0.884 & & & 0.886 & & & 0.833 & & & \\
\hline
\end{tabular}

* These cases only included uterine or ovarian benign diseases.

\section{Diagnostic accuracies for ovarian or uterine tumors}

The diagnostic accuracies for ovarian or endometrial tumors are listed in Table 5.

Table 5

The diagnostic accuracies of DNA methylation, hrHPV and their combination for endometrial and ovarian lesions. hrHPV, high-risk human papillomavirus. N/A, not available. OR, odds ratio. 95\% CI, 95\% confidence interval.

\begin{tabular}{|c|c|c|c|c|c|c|c|c|c|c|c|}
\hline \multirow[t]{2}{*}{ Cervical pathology } & \multicolumn{3}{|c|}{ DNA methylation } & \multicolumn{4}{|l|}{ hrHPV } & \multicolumn{4}{|c|}{ DNA methylation + hrHPV } \\
\hline & n (\%) & OR $(95 \% \mathrm{CI})$ & $p$ & n (\%) & OR $(95 \%$ & & $p$ & $\begin{array}{l}\mathrm{n} \\
(\%)\end{array}$ & OR $(95 \% \mathrm{C}$ & $\overline{\mathrm{CI})}$ & $p$ \\
\hline Normal* $(\mathrm{n}=34)$ & $3(8.8)$ & Reference & - & $\begin{array}{l}2 \\
(5.9)\end{array}$ & Reference & & - & $\begin{array}{l}1 \\
(2.9)\end{array}$ & Reference & & - \\
\hline Ovarian benign diseases $(n=7)$ & $0(0.0)$ & $0.000(0.000-\mathrm{N} / \mathrm{A})$ & 0.999 & $\begin{array}{l}0 \\
(0.0)\end{array}$ & $\begin{array}{l}0.000 \\
\text { N/A) }\end{array}$ & $(0.000-$ & 0.999 & $\begin{array}{l}0 \\
(0.0)\end{array}$ & $\begin{array}{l}0.000 \\
\text { N/A) }\end{array}$ & $(0.000-$ & 0.999 \\
\hline Ovarian borderline diseases $(n=4)$ & $0(0.0)$ & $0.000(0.000-\mathrm{N} / \mathrm{A})$ & 0.999 & $\begin{array}{l}0 \\
(0.0)\end{array}$ & $\begin{array}{l}0.000 \\
\mathrm{~N} / \mathrm{A})\end{array}$ & $(0.000-$ & 0.999 & $\begin{array}{l}0 \\
(0.0)\end{array}$ & $\begin{array}{l}0.000 \\
\mathrm{~N} / \mathrm{A})\end{array}$ & $(0.000-$ & 0.999 \\
\hline Ovarian epithelial carcinomas $(n=41)$ & $\begin{array}{l}5 \\
(12.2)\end{array}$ & $\begin{array}{l}1.435 \\
6.495)\end{array}$ & 0.639 & $\begin{array}{l}1 \\
(2.4)\end{array}$ & $\begin{array}{l}0.400 \\
4.612)\end{array}$ & $(0.035-$ & 0.463 & $\begin{array}{l}0 \\
(0.0)\end{array}$ & $\begin{array}{l}0.000 \\
\text { N/A) }\end{array}$ & $(0.000-$ & 0.998 \\
\hline Normal† $(n=41)$ & $3(7.3)$ & Reference & - & $\begin{array}{l}2 \\
(4.9)\end{array}$ & Reference & & - & $\begin{array}{l}1 \\
(2.4)\end{array}$ & Reference & & - \\
\hline $\begin{array}{l}\text { Endometrial intraepithelial neoplasms } \\
(\mathrm{n}=7)\end{array}$ & $0(0.0)$ & $0.000(0.000-\mathrm{N} / \mathrm{A})$ & 0.999 & $\begin{array}{l}1 \\
(14.3)\end{array}$ & $\begin{array}{l}3.250 \\
41.610)\end{array}$ & $(0.254-$ & 0.365 & $\begin{array}{l}0 \\
(0.0)\end{array}$ & $\begin{array}{l}0.000 \\
\mathrm{~N} / \mathrm{A})\end{array}$ & $(0.000-$ & 0.999 \\
\hline Endometrial carcinomas $(n=40)$ & $\begin{array}{l}22 \\
(55.0)\end{array}$ & $\begin{array}{l}15.481 \\
58.552)\end{array}$ & $<0.001$ & $\begin{array}{l}1 \\
(2.5)\end{array}$ & $\begin{array}{l}0.500 \\
5.743)\end{array}$ & $(0.044-$ & 0.578 & $\begin{array}{l}1 \\
(2.5)\end{array}$ & $\begin{array}{l}1.026 \\
16.979)\end{array}$ & $(0.062-$ & 0.986 \\
\hline
\end{tabular}

* These cases only included benign diseases except for ovarian diseases.

† These cases only included benign diseases.

Benign, borderline and malignant ovarian tumors could not be differentiated from benign diseases other than ovarian diseases by methylation assessment, hrHPV testing or their combination (all p values greater than 0.05 ).

In contrast to benign uterine or ovarian diseases, positive methylation was found in $55.0 \%(22 / 40)$ of endometrial carcinomas $(p<0.001)$. Specifically, one case of clear cell carcinoma had positive results for methylation, while 3 cases of uterine highgrade serous cancer (HGSC) had negative results. Additionally, 7 cases of endometrioid intraepithelial neoplasia (EIN) had negative methylation results. The distributions of positive hrHPV results were similar among benign diseases, EINs and endometrial carcinomas.

Two cases of high-grade endometrial stromal sarcoma and one case of uterine malignant mixed Mullerian tumor had negative methylation results.

\section{Discussion}

A number of studies have explored the role of a panel that includes EPB41L3,[15-24] JAM3,[25] or both[7, 26-30] for the screening or triage of HSIL and/or cervical cancer. In this validation trial, the performance of DNA methylation assessment based on the EPB41L3 and JAM3 genes was similar to that of our training set,[14] and the assessment showed favorable results in identifying CIN2+ or ADC. The sensitivities, specificities, PPVs and NPVs of the methylation assay for CIN2+ in our 
previous and current studies were all equal. These results agreed with those of previous reports.[25, 27, 31] Moreover, the methylation assay was superior to hrHPV testing in terms of specificity and PPV. Although the sensitivity of the methylation assay was lower than that of hrHPV testing, both assays had similar NPVs. Additionally, the OR of the methylation assay was higher than that of hrHPV or HPV 16/18 testing (65.105 versus 14.143 or 7.953). Furthermore, the methylation assay had a similar sensitivity and NPV to those of HPV 16/18 testing but a significantly improved specificity and PPV (Table 2). Even in patients with negative hrHPV results, methylation had good sensitivity and specificity compared with previous reports.[20] However, whether the combination of hrHPV testing plus EPB41L3 and JAM3 methylation assessment could improve diagnostic accuracy was not determined in this validation trial or in the previous training set. In summary, these findings support the independent role of methylation in cervical cancer screening, which is supported by our training set[14] and studies from other authors.[17, 27, 29, 31-33] With modest improvements to the assay technology, DNA methylation testing would probably be able to replace HPV DNA testing altogether.[12] However, the low positivity rates for methylation in CIN2/3 need to be improved to ameliorate the effectiveness of methylation for differentiating CIN2+.

In this trial, for both CIN2/3 and SCC without residual lesions after biopsy or resection, the levels of DNA methylation were 0. This is an interesting finding in that it suggests that DNA methylation is highly disease-specific. In the report of van Baars et al.,[34] in women with multiple cervical biopsies, CADM1/MAL methylation was associated with severity of the lesion and was lesion-specific, which appeared to be representative of the worst lesion, such as CIN3 and cervical cancer. Although the proportions of hrHPV positivity were decreased significantly for CIN2+ without residual lesions compared with CIN2+ with residual lesions, hrHPV testing was not as good for differentiating the two entities as the methylation assay. In fact, in our study, for CIN2+ without residual lesions, methylation levels were similar to those of benign diseases, but the proportions of patients with positive hrHPV testing results were still significantly higher for benign diseases (Table 3). These findings suggest that DNA methylation may be a prognostic marker for CIN2/3 or SCC. However, this hypothesis deserves long-term follow-up.

In the CIN2 group of our training set[34] and current study, we found a lower rate of positive methylation (20.7\% and $17.6 \%$, respectively) than positive hrHPV results (72.4\% and $76.5 \%$, respectively). These differences led to decreased sensitivity for the methylation assay in the context of CIN2+. Host-cell DNA methylation patterns in cervical scrapings from women with CIN2 and CIN3 may be heterogeneous.[35] Some authors have shown that methylation assays have higher NPVs but lower PPVs in CIN3+ than in CIN2+.[7] A DNA methylation panel of host and hrHPV gene (S5 classifier) classifiers showed high potential as a prognostic biomarker to identify progressive CIN2.[36] These findings support the use of methylation pattern assessments together with other diagnostic procedures, including immunostaining for specific markers, for in-depth analyses of CIN2.[37, 38]

In our training set[34] and current study, we observed good diagnostic accuracies for methylation assessment or hrHPV testing in cervical ADC. Unsurprisingly, methylation was best for identifying endocervical ADC, the most common type of ADC. According to the International Endocervical Adenocarcinoma Criteria and Classification (IECC),[39] ADCs of the in situ, endocervical, mucinous or villoglandular type are HPV-associated ADCs. ADC and SCC may have differential methylation patterns.[40] Aberrantly high methylation of ZNF582 may even be a potential biomarker for determining ADC prognosis and chemoradiotherapy resistance.[41] Hence, a larger sample with multiple subtypes of ADC is needed to verify and confirm the differences between methylation assessment and hrHPV testing for ADC diagnosis.

A number of reports have revealed the favorable performance of DNA methylation assessment of endometrial cancer tissues, [42-47] ovarian cancer tissues,[48-50] or both.[51, 52] In our current study, we enrolled more patients with endometrial and ovarian tumors (Table 5). Regarding ovarian tumors, only $12.2 \%$ of patients with EOC had positive methylation expression; however, DNA methylation was detected in more than half (55.0\%) of endometrial carcinomas. These differences reflect the limitations of cytological pathology in the diagnosis of endometrial or ovarian tumors. To assess methylation in uterine malignancies, an intrauterine tool may be able to obtain higher number methylation-positive cells than a cervical swab. In addition, 7 cases of EIN were negative for methylation. There is very limited evidence of methylation in uterine or ovarian precancerous lesions. Overexpression of DNA methyltransferase 1 microRNA is mainly observed in endometrial carcinomas 
rather than normal tissues or EINs.[53] In the study by Marichereda et al.,[54] methylation of the SFRP2 gene in the endometrial tissues of patients with hyperplastic processes was above $20-25 \%$. However, gene ontology analysis has shown differential methylation at linked CpG sites between low-grade serous carcinomas and serous borderline tumors.[55]

The strength of this study is its relatively large cohort with unselected gynecologic diseases. The detailed pathological results before and after major surgery (also before and after methylation assessment) provide robust validation of EPB41L3 and $J A M 3$ as tools for cervical and even endometrial lesion screening. However, there are several limitations in our study. First, we did not compare the methylation assay results to the cytology results. As most patients with cervical lesions underwent cervical procedures before the last surgery (median time 40 days), we doubted that the results of the cytology assay would be unaffected by surgery. DNA methylation analysis of HPV-positive self-obtained samples was not inferior to cytology triage in the detection of CIN2+.[56] The effectiveness of methylation assessment versus cytology with or without hrHPV testing should be assessed in community-based population in the future. Second, we did not follow up on the prognosis of the patients after major surgery, limiting the interpretation of DNA methylation results in the carcinogenesis and progression of cervical cancer.[57] Third, we excluded patients who were positive for HIV from the training and validation sets. This limitation would hamper the extrapolation of the DNA methylation assay to a large cohort, as reported previously.[58, 59] Lastly, the relatively low prevalence of positive methylation in CIN2/3 indicates that further pathological and molecular analysis is needed for these pathological types.

\section{Conclusion}

In this validation trial from China, we discovered that methylation of EPB41L3 plus JAM3 had a favorable diagnostic accuracy for $\mathrm{CIN} 2+$, which is consistent with our previous training set. Our findings suggest the methylation assessment of the EPB41L3 and JAM3 genes could be an independent screening method regardless of hrHPV status. Specifically, methylation assessment of liquid-based samples is favorable for identifying cervical ADCs and endometrial carcinomas.

\section{Abbreviations}

95\% Cls - 95\% confidence intervals

ADCs - cervical adenocarcinomas

CIN - cervical intraepithelial neoplasia

CIN2+ - CIN2 or more severe lesions

hrHPV - high-risk human papillomavirus

HSIL - high-grade intraepithelial lesions

LEEP - loop electrosurgical excision procedure

NPV - negative predictive value

OR - odds ratio

PCR - polymerase chain reaction

PPV - positive predictive value

SCC - squamous cell carcinoma

\section{Declarations}




\section{Ethics approval and consent to participate}

The institutional review board of Peking Union Medical College Hospital has approved this study (No. JS-1954). The registration number is NCT03960879 (clinicaltrials.gov, registered on May 23, 2019).

\section{Consent for publication}

Consent for publication has been obtained from every patient.

\section{Availability of data and materials}

All data for this study are included in the supplemental file.

\section{Competing interests}

All authors declare that they have no conflicts of interest to disclose.

\section{Funding}

This study is supported by the Chinese Academy of Medical Sciences Initiative for Innovative Medicine (CAMS-2017-I2M-1002). The funders had no role in the study design, data collection and analysis, decision to publish, or preparation of the manuscript.

\section{Authors' contributions}

PL and LL conceived of the original idea for the study, interpreted the results, carried out the statistical analysis, edited the paper and were the overall guarantors. LK, LW, ZW, XX and LL obtained ethical approval, collected study samples, contributed to the preparation of the data set, interpreted the results and contributed to drafting the paper. LW, ZW and PL carried out the DNA methylation analysis. YY and HW conducted the pathological evaluations. XX and MW contributed to the study design and interpretation of results and commented on drafts of the paper. All authors have approved the final version of the manuscript.

\section{Acknowledgements}

None

\section{References}

1. Bray F, Ferlay J, Soerjomataram I, Siegel RL, Torre LA, Jemal A. Global cancer statistics 2018: GLOBOCAN estimates of incidence and mortality worldwide for 36 cancers in 185 countries. CA Cancer J Clin. 2018;68:394-424.

2. Chen W, Zheng R, Baade PD, et al. Cancer statistics in China, 2015. CA Cancer J Clin. 2016;66:115-32.

3. National Health Commission Of The People's Republic Of China. Chinese guidelines for diagnosis and treatment of cervical cancer 2018 (English version). Chin J Cancer Res. 2019;31:295-305.

4. Miller KD, Siegel RL, Lin CC, et al. Cancer treatment and survivorship statistics, 2016. CA Cancer J Clin. 2016;66:271-89.

5. Saslow D, Solomon D, Lawson HW, et al. American Cancer Society, American Society for Colposcopy and Cervical Pathology, and American Society for Clinical Pathology screening guidelines for the prevention and early detection of cervical cancer. J Low Genit Tract Dis. 2012;16:175-204.

6. Massad LS, Einstein MH, Huh WK, et al. 2012 updated consensus guidelines for the management of abnormal cervical cancer screening tests and cancer precursors. J Low Genit Tract Dis. 2013;17:S1-S27.

7. van Leeuwen RW, Ostrbenk A, Poljak M, van der Zee AGJ, Schuuring E, Wisman GBA. DNA methylation markers as a triage test for identification of cervical lesions in a high risk human papillomavirus positive screening cohort. Int $\mathrm{J}$ 
Cancer. 2019;144:746-54.

8. Ebisch RM, Siebers AG, Bosgraaf RP, Massuger LF, Bekkers RL, Melchers WJ. Triage of high-risk HPV positive women in cervical cancer screening. Expert Rev Anticancer Ther. 2016;16:1073-85.

9. Cuschieri K, Ronco G, Lorincz A, et al. Eurogin roadmap 2017: Triage strategies for the management of HPV-positive women in cervical screening programs. Int J Cancer. 2018;143:735-45.

10. Egger G, Liang G, Aparicio A, Jones PA. Epigenetics in human disease and prospects for epigenetic therapy. Nature. 2004;429:457-63.

11. Jones PA, Baylin SB. The fundamental role of epigenetic events in cancer. Nat Rev Genet. 2002;3:415-28.

12. Lorincz AT. Virtues and Weaknesses of DNA Methylation as a Test for Cervical Cancer Prevention. Acta Cytol. 2016;60:501-12.

13. Lorincz AT. Cancer diagnostic classifiers based on quantitative DNA methylation. Expert Rev Mol Diagn. 2014;14:293305.

14. Kong L, Wang L, Wang Z, et al. DNA methylation for cervical cancer screening: a training set in China. Clin Epigenetics. 2020;12:91.

15. Kelly H, Benavente Y, Pavon MA, De Sanjose S, Mayaud P, Lorincz AT. Performance of DNA methylation assays for detection of high-grade cervical intraepithelial neoplasia (CIN2+): a systematic review and meta-analysis. $\mathrm{Br} \mathrm{J}$ Cancer. 2019;121:954-65.

16. Hernandez-Lopez R, Lorincz AT, Torres-Ibarra L, et al. Methylation estimates the risk of precancer in HPV-infected women with discrepant results between cytology and HPV16/18 genotyping. Clin Epigenetics. 2019;11:140.

17. Rogeri CD, Silveira HCS, Causin RL, et al. Methylation of the hsa-miR-124, SOX1, TERT, and LMX1A genes as biomarkers for precursor lesions in cervical cancer. Gynecol Oncol. 2018;150:545-51.

18. Kelly HA, Chikandiwa A, Warman R, et al. Associations of human gene EPB41L3 DNA methylation and cervical intraepithelial neoplasia in women living with HIV-1 in Africa. AIDS. 2018;32:2227-36.

19. Clarke MA, Luhn P, Gage JC, et al. Discovery and validation of candidate host DNA methylation markers for detection of cervical precancer and cancer. Int J Cancer. 2017;141:701-10.

20. Lorincz AT, Brentnall AR, Scibior-Bentkowska D, et al. Validation of a DNA methylation HPV triage classifier in a screening sample. Int J Cancer. 2016;138:2745-51.

21. Louvanto K, Franco EL, Ramanakumar AV, et al. Methylation of viral and host genes and severity of cervical lesions associated with human papillomavirus type 16. Int J Cancer. 2015;136:E638-45.

22. Brentnall AR, Vasiljevic N, Scibior-Bentkowska D, et al. HPV33 DNA methylation measurement improves cervical precancer risk estimation of an HPV16, HPV18, HPV31 and \textit\{EPB41L3\} methylation classifier. Cancer Biomark. 2015;15:669-75.

23. Blanco-Luquin I, Guarch R, Ojer A, et al. Differential role of gene hypermethylation in adenocarcinomas, squamous cell carcinomas and cervical intraepithelial lesions of the uterine cervix. Pathol Int. 2015;65:476-85.

24. Brentnall AR, Vasiljevic N, Scibior-Bentkowska D, et al. A DNA methylation classifier of cervical precancer based on human papillomavirus and human genes. Int J Cancer. 2014;135:1425-32.

25. Guo Z, Hu Y, Yuan L, Li N, Wang T. A prospective study on the predictive value of DNA methylation in cervical intraepithelial neoplasia prognosis. Arch Gynecol Obstet. 2018;298:589-96.

26. Boers A, Bosgraaf RP, van Leeuwen RW, et al. DNA methylation analysis in self-sampled brush material as a triage test in hrHPV-positive women. Br J Cancer. 2014;111:1095-101.

27. Boers $A$, Wang R, van Leeuwen RW, et al. Discovery of new methylation markers to improve screening for cervical intraepithelial neoplasia grade 2/3. Clin Epigenetics. 2016;8:29.

28. Eijsink JJ, Lendvai A, Deregowski V, et al. A four-gene methylation marker panel as triage test in high-risk human papillomavirus positive patients. Int J Cancer. 2012;130:1861-9. 
29. Eijsink JJ, Yang N, Lendvai A, et al. Detection of cervical neoplasia by DNA methylation analysis in cervico-vaginal lavages, a feasibility study. Gynecol Oncol. 2011;120:280-3.

30. Vasiljevic N, Scibior-Bentkowska D, Brentnall AR, Cuzick J, Lorincz AT. Credentialing of DNA methylation assays for human genes as diagnostic biomarkers of cervical intraepithelial neoplasia in high-risk HPV positive women. Gynecol Oncol. 2014;132:709-14.

31. Kahn SL, Ronnett BM, Gravitt PE, Gustafson KS. Quantitative methylation-specific PCR for the detection of aberrant DNA methylation in liquid-based Pap tests. Cancer. 2008;114:57-64.

32. Wisman GB, Nijhuis ER, Hoque MO, et al. Assessment of gene promoter hypermethylation for detection of cervical neoplasia. Int J Cancer. 2006;119:1908-14.

33. Lin CJ, Lai HC, Wang KH, et al. Testing for methylated PCDH10 or WT1 is superior to the HPV test in detecting severe neoplasms (CIN3 or greater) in the triage of ASC-US smear results. Am J Obstet Gynecol. 2011;204:21 e1-7.

34. van Baars R, van der Marel J, Snijders PJ, et al. CADM1 and MAL methylation status in cervical scrapes is representative of the most severe underlying lesion in women with multiple cervical biopsies. Int J Cancer. 2016;138:463-71.

35. Verlaat W, Van Leeuwen RW, Novianti PW, et al. Host-cell DNA methylation patterns during high-risk HPV-induced carcinogenesis reveal a heterogeneous nature of cervical pre-cancer. Epigenetics. 2018;13:769-78.

36. Louvanto K, Aro K, Nedjai B, et al. Methylation in predicting progression of untreated high-grade cervical intraepithelial neoplasia. Clin Infect Dis. 2019.

37. Gage JC, Schiffman M, Hunt WC, et al. Cervical histopathology variability among laboratories: a population-based statewide investigation. Am J Clin Pathol. 2013;139:330-5.

38. Guo M, Hu L, Baliga M, He Z, Hughson MD. The predictive value of p16(INK4a) and hybrid capture 2 human papillomavirus testing for high-grade cervical intraepithelial neoplasia. Am J Clin Pathol. 2004;122:894-901.

39. Stolnicu S, Barsan I, Hoang L, et al. International Endocervical Adenocarcinoma Criteria and Classification (IECC): A New Pathogenetic Classification for Invasive Adenocarcinomas of the Endocervix. Am J Surg Pathol. 2018;42:214-26.

40. Lee EJ, McClelland M, Wang Y, Long F, Choi SH, Lee JH. Distinct DNA methylation profiles between adenocarcinoma and squamous cell carcinoma of human uterine cervix. Oncol Res. 2010;18:401-8.

41. Wu NY, Zhang X, Chu T, et al. High methylation of ZNF582 in cervical adenocarcinoma affects radiosensitivity and prognosis. Ann Transl Med. 2019;7:328.

42. Huang RL, Su PH, Liao YP, et al. Integrated Epigenomics Analysis Reveals a DNA Methylation Panel for Endometrial Cancer Detection Using Cervical Scrapings. Clin Cancer Res. 2017;23:263-72.

43. Kim GE, Kweon SS, Lee JS, Lee JH, Nam JH, Choi C. Quantitative assessment of DNA methylation for the detection of cervical and endometrial adenocarcinomas in liquid-based cytology specimens. Anal Quant Cytopathol Histpathol. 2012;34:195-203.

44. Wang Y, Liu D, Jin X, Song H, Lou G. Genome-wide characterization of aberrant DNA methylation patterns and the potential clinical implications in patients with endometrial cancer. Pathol Res Pract. 2019;215:137-43.

45. Cui ZJ, Zhou XH, Zhang HY. DNA Methylation Module Network-Based Prognosis and Molecular Typing of Cancer. Genes (Basel). 2019;10.

46. Ying J, Xu T, Wang Q, Ye J, Lyu J. Exploration of DNA methylation markers for diagnosis and prognosis of patients with endometrial cancer. Epigenetics. 2018;13:490-504.

47. Bakkum-Gamez JN, Wentzensen N, Maurer MJ, et al. Detection of endometrial cancer via molecular analysis of DNA collected with vaginal tampons. Gynecol Oncol. 2015;137:14-22.

48. Yang Y, Wu L, Shu X, et al. Genetic Data from Nearly 63,000 Women of European Descent Predicts DNA Methylation Biomarkers and Epithelial Ovarian Cancer Risk. Cancer Res. 2019;79:505-17.

49. Ishak CA, Lheureux S, De Carvalho DD. DNA Methylation as a Robust Classifier of Epithelial Ovarian Cancer. Clin Cancer Res. 2019;25:5729-31. 
50. Lin HW, Fu CF, Chang MC, et al. CDH1, DLEC1 and SFRP5 methylation panel as a prognostic marker for advanced epithelial ovarian cancer. Epigenomics. 2018;10:1397-413.

51. Chang CC, Wang HC, Liao YP, et al. The feasibility of detecting endometrial and ovarian cancer using DNA methylation biomarkers in cervical scrapings. J Gynecol Oncol. 2018;29:e17.

52. Kolbe DL, DeLoia JA, Porter-Gill P, et al. Differential analysis of ovarian and endometrial cancers identifies a methylator phenotype. PLoS One. 2012;7:e32941.

53. Ikeda S, Imura J, Suzuki K. Protein expression, mRNA expression and gene amplification of DNA methyltransferase 1 in endometrial tumor tissues. Mol Clin Oncol. 2013;1:423-9.

54. Marichereda VG, Bykovsmall a CNA, Bubnov VV, et al. The analysis of methylation of DNA promoter of SFRP2 gene in patients with hyperplastic processes of the endometrium. Exp Oncol. 2018;40:109-13.

55. Zeller C, Dai W, Curry E, et al. The DNA methylomes of serous borderline tumors reveal subgroups with malignant- or benign-like profiles. Am J Pathol. 2013;182:668-77.

56. Verhoef VM, Bosgraaf RP, van Kemenade FJ, et al. Triage by methylation-marker testing versus cytology in women who test HPV-positive on self-collected cervicovaginal specimens (PROHTECT-3): a randomised controlled non-inferiority trial. Lancet Oncol. 2014;15:315-22.

57. Shen F, Zheng H, Zhou L, Li W, Liu J, Xu X. Identification of CD28 and PTEN as novel prognostic markers for cervical cancer. J Cell Physiol. 2019;234:7004-11.

58. Kremer WW, Van Zummeren M, Novianti PW, et al. Detection of hypermethylated genes as markers for cervical screening in women living with HIV. J Int AIDS Soc. 2018;21:e25165.

59. Kim HJ, Kim CY, Jin J, et al. Aberrant single-minded homolog 1 methylation as a potential biomarker for cervical cancer. Diagn Cytopathol. 2018;46:15-21.

\section{Figures}




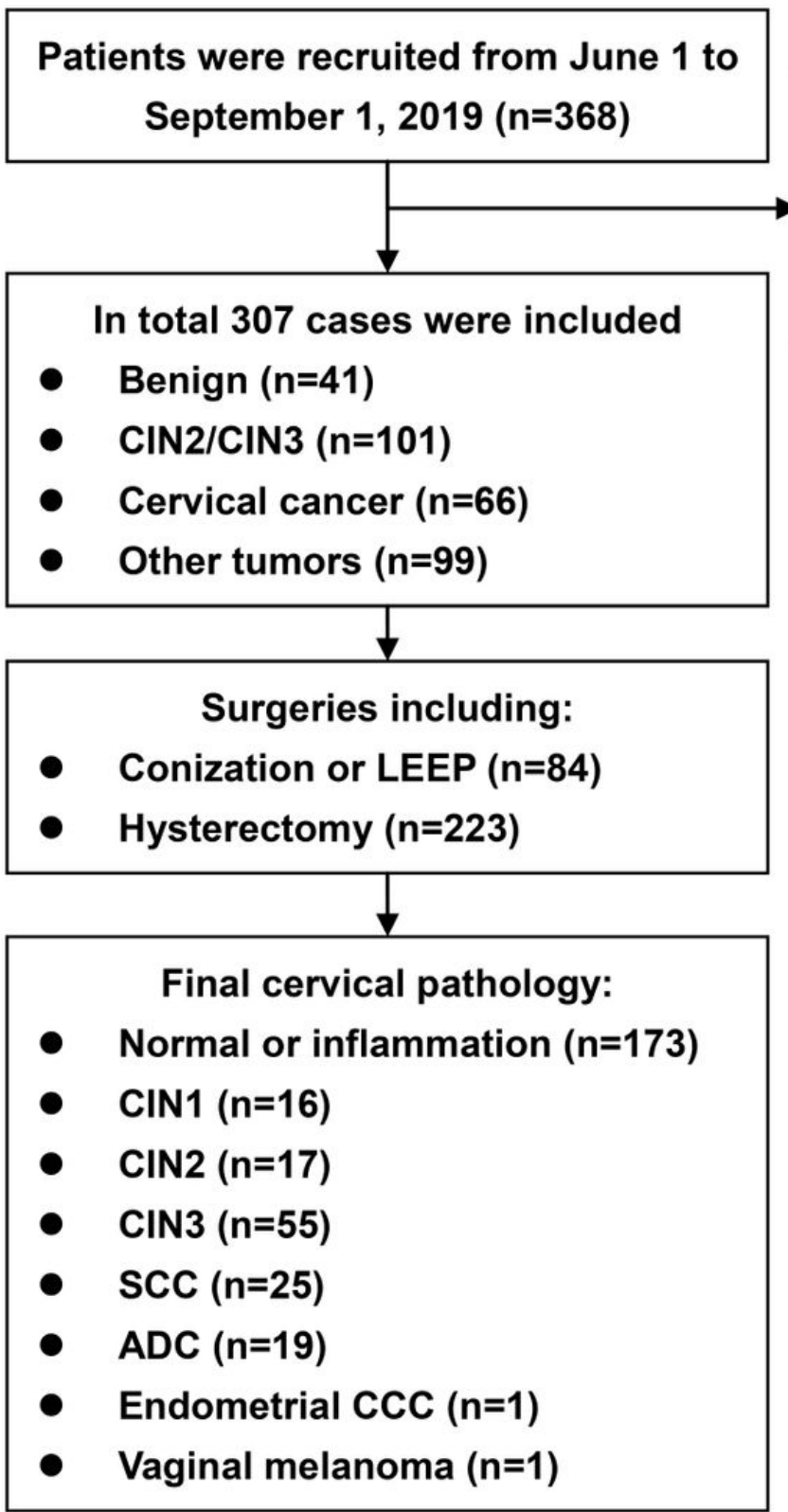

$$
\text { Exclusion }(n=61) \text { : }
$$

Not meeting the inclusion criteria $(n=8)$

Not willing to participate the study $(n=48)$

Unable to provide cytology sample $(n=5)$

Figure 1

Figure 1

Flow diagram of the study. ADC, adenocarcinoma. CCC, clear cell carcinoma. CIN, cervical intraepithelial neoplasm. LEEP, loop electrosurgical excision procedure. SCC, squamous cell carcinoma.

\section{Supplementary Files}

This is a list of supplementary files associated with this preprint. Click to download.

- Supplement1.xlsx 